\title{
Ecology and biogeochemistry of cyanobacteria in soils, permafrost, aquatic and cryptic polar habitats
}

\author{
Thulani P. Makhalanyane ${ }^{1} \cdot$ Angel Valverde $^{1} \cdot$ \\ David Vela'zquez ${ }^{2} \cdot$ Eoin Gunnigle ${ }^{1}$. \\ Marc W. Van Goethem ${ }^{1}$ - Antonio Quesada ${ }^{2}$. \\ Don A. Cowan ${ }^{1}$
}

\author{
${ }^{1}$ Department of Genetics, Centre for Microbial Ecology and Genomics, University of Pretoria, Pretoria \\ 0028, South Africa \\ ${ }^{2}$ Departamento de Biologia, Universidad Autonoma de Madrid, 28049 Madrid, Spain
}

Correspondence author: Don A. Cowan don.cowan@up.ac.za

\begin{abstract}
Polar Regions (continental Antarctica and the Arctic) are characterized by a range of extreme environmental conditions, which impose severe pressures on biological life. Polar cold-active cyanobacteria are uniquely adapted to withstand the environmental conditions of the high latitudes. These adaptations include high ultra-violet radiation and desiccation tolerance, and mechanisms to protect cells from freeze-thaw damage. As the most widely distributed photoautotrophs in these regions, cyanobacteria are likely the dominant contributors of critically essential ecosystem services, particularly carbon and nitrogen turnover in terrestrial polar habitats. These habitats include soils, permafrost, cryptic niches (including biological soil crusts, hypoliths and endoliths), ice and snow, and a range of aquatic habitats. Here we review current literature on the ecology, and the functional role played by cyanobacteria in various Arctic and Antarctic environments. We focus on the ecological importance of cyanobacterial communities in Polar Regions and assess what is known regarding the toxins they produce. We also review the responses and adaptations of cyanobacteria to extreme environments.
\end{abstract}

Keywords Cyanobacteria $\cdot$ Antarctica $\cdot$ Arctic $\cdot$ Soil $\cdot$ Aquatic $\cdot$ Cryptic niches biogeochemistry 


\section{Introduction}

The severe environmental conditions of continental Antarctica and high Arctic $\left(>80^{\circ} \mathrm{N}\right)$ terrestrial habitats, which include freeze-thaw cycles, wide irradiance fluctuations (including Photosynthetically Active Radiation (PAR) and UV), and low nutrient supplies, results in generally depauperate habitats and very short seasons for biological growth (Cary et al. 2010; Convey et al. 2014; Cowan et al. 2014). The variability in the environmental factors, together with the less than ideal levels of nutrients required for biological activity, severely restrict microbial communities in polar environments. In the absence of other photoautotrophic clades, it is accepted that cyanobacteria are largely responsible for providing the most important ecosystem services, and that cyanobacterial autotrophy supports substantial and diverse populations of heterotrophic microorganisms (such as Actinobacteria, Proteobacteria, Firmicutes and Bacteroidetes) together with smaller numbers of organisms in higher trophic levels (Aislabie et al. 2006; Babalola et al. 2009; Chan et al. 2012; Stomeo et al. 2012; Makhalanyane et al. 2013a; de los Rios et al. 2014; Yung et al. 2014).

Both classical and modern microbiological techniques have highlighted the presence of cyanobacteria in a wide range of terrestrial Arctic and Antarctic niches, including permafrost (Jansson and Tas, 2014), ice shelves (Vincent et al. 2004; Bottos et al. 2008), rocks (Chan et al. 2012; de los Rios et al. 2014; Makhalanyane et al. 2014), ponds and lakes (Taton et al. 2003b; Bonilla et al. 2005), glaciers and the resulting meltwater streams (Nadeau and Castenholz 2000; Jungblut et al. 2005), and mineral soils (Wood et al. 2008b; Lee et al. 2012; Makhalanyane et al. 2013a). Cyanobacteria are thought to be the primary colonizers in these niches (Vincent 2000), and are known to contribute to structural stability, moisture retention and fertility (Belnap and Gardner 1993). Indeed, microbial components of cyanobacteria-driven biofilms produce large amount of exopolysaccharides (EPS), generating an exopolymer matrix where the biological and biogeochemical interactions take place (Paerl and Pinckney 1996; Nichols et al. 2005). This EPS matrix also plays an important structural role in these microbial consortia (Dupraz et al. 2009; de los Rios et al. 2014) and is responsible for the creation and maintenance of microenvironments within relatively spacious pores (Vézina and Vincent 1997; Krembs et al. 2002). EPS also facilitates important buffering, cryoprotection and desiccation protection for a wide range of microorganisms (de los Rios et al. 2014).

Due to the extensive latitudinal range, conditions are completely different between maritime and continental Antarctica. In the high latitude zones $\left(>80^{\circ} \mathrm{S}\right)$, as a direct consequence of the stringent environmental conditions present, plants are nearly or completely absent and cyanobacteria constitute the dominant photoautotrophs (Cary et al. 2010). This is comparable with the high arctic $\left(>80^{\circ} \mathrm{N}\right)$ even though this region is relatively warmer and has numerous lakes, ponds and flowing water bodies. These polar cyanobacterial cohorts are usually present with a number of eukaryotic photoautotrophs including di-atoms, green algae and/or mixotrophic organisms (Vela'zquez et al. 2011). It is widely accepted however that cyanobacteria are responsible for sustaining crucial ecosystem services in high latitude Polar Regions.

An extensive array of research has been undertaken recently on polar-based cyanobacterial populations and their imprint on these systems. Given the ecological importance of cyanobacteria in these fragile areas that are strongly influenced by climate change (e.g. the Antarctic Peninsula as well as some regions in the Arctic have experienced some of the most rapid air temperature increases on Earth (Turner et al. 2002; Steig and Orsi 2013)), this work has significant merit. For example, cyanobacteria may represent 
important indicator species for understanding how such changes will affect ecosystem dynamics in polar habitats (Curtis 2006). Cyanobacterial nomenclature remains contentious and this has been discussed elsewhere (Oren 2011, 2014). In this review, we present the relevant information towards examining the importance of cyanobacterial populations in different microhabitats spread across the Polar Regions. Firstly, we examine the specific polar niches giving an in-depth account of the cyanobacterial populations therein. We then focus on the functional significance of polar cyanobacteria before extracting some conclusions and proposing some fruitful avenues for future research. We have not focused on cyanobacteria in seepage habitats, which are also prominent polar regions, however these are reviewed elsewhere (Koma'rek et al. 2008; Koma'rek and Koma'rek 2010).

\section{Soils}

A considerable proportion of the Antarctic continental surface is permanently covered by an expansive ice-sheet, with less than $4 \%$ of the total landmass being ice-free (Cowan and Ah Tow 2004; Convey et al. 2014). These ice-free areas include mountain ranges, nunatuks and coastal deserts, some of which are bare depauperate arid soils. These regions offer a wide array of chemistries (Lee et al. 2012) and soil types (Bockheim and McLeod 2008), and can be readily distinguished on the basis of morphological properties, particularly the amount and distribution of soluble salts and the degree of chemical weathering. For instance, the dominant soil types in the McMurdo Dry Valleys (MDV) include Typic Anhyorthels, Typic Haploturbels and Typic Anhyturbels, while the dominant soils on the Antarctic Peninsula are of ornithogenic origin (Ugolini and Bockheim 2008), although vegetation present in this region allows for more developed soils (Otero et al. 2013). High Arctic soil cover is present as an 'active layer' overlying thick permafrost, which is limited to wind swept small islands, narrow strips of terraces and colluvial foothills (Kimble 2004) with about 2 months of ice-free conditions during summer where temperatures rise above $0{ }^{\circ} \mathrm{C}$.

In Antarctica, the differences in soil types between the Peninsula region and the MDVs are likely to directly affect the soil dynamics and possibly lead to distinctions in cyanobacterial community structure. A study assessing the relationship between Antarctic soil classification and bacterial diversity reported that there were no resulting differences in diversity as a consequence of soil classification (Aislabie et al. 2008). This is a surprising finding, as it has been shown that soil types influence bacterial community structure and composition (Fierer et al. 2003; Fierer and Jackson 2006), suggesting that this relationship may need further interrogation in Antarctic soils (Van Horn et al. 2013). Indeed, a study undertaken in the high Arctic (Kaštovska' et al. 2005) found that although there was a predominance of cyanobacteria sp. in the four soil types analysed (subglacial and deglaciated), physicochemical parameters (soil texture and water content) were found to be important drivers of diversity and abundance.

The distribution of cyanobacteria in Antarctic soil seems to be largely influenced by both contemporary and past events. Firstly, cyanobacterial distribution may respond to environmental gradients (i.e. they exhibit biogeographical patterns). For example, cyanobacterial abundance has been shown to be linked to latitudinal gradients, with the highest diversity of cyanobacteria between $70^{\circ} \mathrm{S}$ and $80^{\circ} \mathrm{S}$ (Namsaraev et al. 2010), although these authors also reported that $79 \%$ of Antarctic terrestrial cyanobacterial have a cosmopolitan distribution. Similarly, cyanobacterial diversity at Mars Oasis and Ellsworth Mountains sites demonsted clear distributional patterns across latitudinal zones 
Yergeau et al. (2007) (Table 1). This study also demonstrated that cyanobacteria from Antarctic soils may follow similar distribution patterns as those from marine environments (Ferna'ndez et al. 2010; Zehr 2011). More studies encompassing larger datasets using modern molecular microbiology approaches (e.g. high-throughput sequencing) may shed more light on these distributional patterns.

Secondly, it has been suggested that soil cyanobacteria may represent historical signatures of aquatic cyanobacterial mat biomass distributed from lake margins by aeolian processes (Vincent 2000; Harding et al. 2011). This suggestion is supported by the demonstration that cyanobacteria in soils of the low altitude maritime Miers Valley were similar to those from nearby microbial mats (Wood et al. 2008b). However, the presence of specialised cryptic cyanobacterial-dominated lithic communities (see below) suggests that lake-derived cyanobacterial biomass does not fully account for cyanobacterial diversity in Antarctic terrestrial habitats.

\section{Cryptic niches}

Cryptic and refuge niches (namely biological soil crusts (BSCs), hypoliths, and endoliths) support the most specialised and unique microbial communities in the Polar Regions (Fig. 1). While these niches may be physically dominated by cyanobacteria, they include a wide range of bacterial and fungal phylotypes. BSCs are found on soil surfaces, while lithic communities depend on the mineral substrate (Vincent 2004; Bu del and Colesie

Table 1 Cyanobacterial diversity from five distinct Dry Valley niches

\begin{tabular}{|c|c|c|c|c|c|}
\hline \multirow[t]{2}{*}{ Cyanobacterial taxon } & \multicolumn{5}{|l|}{ Niche } \\
\hline & Hypolith & Chasmoendolith & Cryptoendolith & Soil & Mat \\
\hline Acaryochloris & & $*$ & & & $*$ \\
\hline Anabaena & & & & $*$ & $*$ \\
\hline Chroococcidiopsis & $*$ & $*$ & * & $*$ & $*$ \\
\hline Cylindrospermum & & & & $*$ & \\
\hline Gloeocapsa & & $*$ & $*$ & & \\
\hline Hormathonema & & & $*$ & & \\
\hline Leptolyngbya frigida & $*$ & $*$ & $*$ & $*$ & $*$ \\
\hline Lyngbya & & & & $*$ & $*$ \\
\hline Microcoleus vaginatus & & & & $*$ & \\
\hline Nodularia & & & & & $*$ \\
\hline Nostoc & $*$ & $*$ & $*$ & $*$ & $*$ \\
\hline Oscillatoria & $*$ & & & $*$ & $*$ \\
\hline Phormidium & & & $*$ & $*$ & $*$ \\
\hline Plectonema & & & $*$ & & \\
\hline Schizothrix & & & & & $*$ \\
\hline Synechococcus & & $*$ & & $*$ & \\
\hline
\end{tabular}

Compiled using data from Bahl et al. (2011), Cary et al. (2010), Chan et al. (2012), Cowan and Tow (2004), Cowan et al. (2011), De La Torre et al. (2003), Friedmann et al. (1988), Jungblut et al. (2005), Khan et al. (2011), Pointing et al. (2009), Smith et al. (2006), Taton et al. (2003a, b), Wong et al. (2010), and Wood et al. $(2008 \mathrm{a}, \mathrm{b})$ 

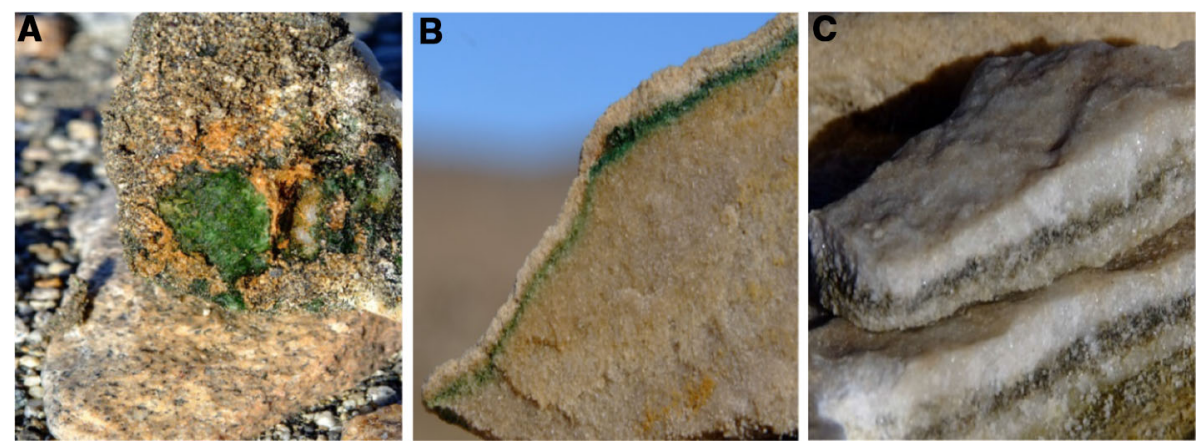

Fig. 1 a An upturned hypolith community. The green biofilm layer is distinctive of cyanobacteria-dominated type I hypoliths. b Green cryptoendoliths colonise porous rocks such as sandstone a few millimetres below the rock surface. c Black endoliths are shown here-pigmented fungal colonisers provide the observed colouration. (Color figure online)

2014; Makhalanyane et al. 2014). BSCs are a dominant feature of many semi-arid and arid environments, and are thought to significantly improve the stability and nutrient status of soils (Belnap and Lange 2002). Hypolithic communities are restricted to the ventral and lateral surfaces of translucent rocks, while endolithic communities are found embedded in porous sandstones and weathered granitic rocks (Makhalanyane et al. 2015). Both niches provide the physical stability which allow slow-growing cyanobacteria to develop (Castenholz 1988; Agawin and Agusti 1997).

\section{Biological soil crusts}

BSCs are good model systems in community, landscape and ecosystem ecology (Bowker et al. 2014; Makhalanyane et al. 2015). Non-polar regions BSCs are often dominated by a singular filamentous species of the genus Microcoleus: M. vaginatus (Belnap 2003; GarciaPichel et al. 2013; B "u del et al. 2014), whereas Antarctic BSCs are unique to the extent that this species has only been identified from Schirmacher Oasis (Pankow et al. 1991) and Windmill Islands (Ling and Seppelt 1998) sites. The majority of Antarctic BSCs are composed of filamentous cyanobacteria such as Nostoc commune and Tolypothrix, Calothrix and Leptolyngbya species (Bu"del and Colesie 2014). Interestingly, no cyanobacteria were identified in a recent microscopic survey of BSCs from the Diamond Hill area of East Antarctica, in contrast to other Antarctic environments (Pointing and Belnap 2012). This discrepancy may be due to the use of light microscopy and the failure to identify cells at low abundance, rather than the complete absence of cyanobacterial taxa. In the northern land limit of the high Arctic, members of Nostocales, Chroococcales and Oscillatoria were found in BSC communities adjacent to Ward Hunt Lake (Steven et al. 2013). Here it was shown that the filamentous Oscillatoriales-related cyanobacteria consistently increased inside water catchment soil when compared to dry soil, suggesting that these may be hotspots for primary production in this region.

Studies from temperate zones have demonstrated that increasing environmental temperatures can result in a significant reduction in richness and diversity of biological soil crust communities (Escolar et al. 2012). In Antarctic regions (particularly the Antarctic Peninsula), which are subjected to substantial warming trends, it is projected that the growth and diversity of BSCs will also be reduced. This is also the case with BSC 
productivity in the High Arctic (Yoshitake et al. 2010). Such changes are likely to result in diminished ecosystem functionality, nutrient cycling, soil stabilization, and water dynamics (Castillo-Monroy et al. 2010; Escolar et al. 2012; Maestre et al. 2013; Bowker et al. 2014; B "u del et al. 2014; Makhalanyane et al. 2015). Antarctic BSCs have recently been comprehensively reviewed by Büdel and Colesie (2014) and by Pointing and Belnap (2012).

\section{Hypoliths}

The underside of rocks in climatically extreme deserts acts as a 'refuge' niche for photosynthetic microorganisms (defined as 'hypoliths') and their community (the 'hypolithon') (Pointing et al. 2009; Chan et al. 2012; Makhalanyane et al. 2013b, 2014; Ramond et al. 2015), where they photosynthesise at irradiance levels less than $0.1 \%$ of the incident light (Schlesinger et al. 2003). Here, the community is protected from abiotic stressors such as harsh ultraviolet radiation and wind scouring, with trapped moisture providing bioavailable liquid water. Interestingly, Cyanobacteria have been found to form the basis for community structure and functional processes in hot deserts (Valverde et al. 2015).

Hypolithic communities have been reported from a number of Dry Valleys in the East Antarctic region and in other ice-free areas, with these sub-lithic communities typically dominated by cyanobacteria (Cowan et al. 2010; Khan et al. 2011; de los Rios et al. 2014). Antarctic hypolithic communities have been surveyed in considerable detail (Smith et al. 2000; Wood et al. 2008b; Pointing et al. 2009; Makhalanyane et al. 2013a). A clone library based analysis of hypolith samples indicated that sequences with close homology to Nostocales and Oscillatoriales were dominant (Khan et al. 2011). Microscopic examination of colonized quartz rocks also showed a dominance of oscillatorian cyanobacterial morphotypes, probably of the genus Leptolyngbya (Pointing et al. 2009). A recent study by de los Rios et al. (2014) used electron microscopy to assess the spatial distribution of hypolithic communities in the Miers Valley. The authors showed that cyanobacteriadominated hypoliths displayed a layered spatial organization structured by filamentous cyanobacteria and associated extracellular polymeric components (de los Rios et al. 2014). The presence of EPS was proposed to facilitate the survival of cyanobacteria in this waterlimited environment, through improving water retention.

The Arctic hypoliths are also dominated by cyanobacteria. Species found include Gloeocapsa cf. atrata Kützing, Gloeocapsa cf. punctata Na“geli, Gloeocapsa cf. kuetzingiana Na"geli and Chroococcidiopsis-like cells; unicellular algal chlorophytes are also present (Cockell and Stokes 2004). Strikingly, the annual primary production of hypoliths on Devon Island (Nunavut, Canada) was estimated to be similar to plants, lichens and bryophytes (Cockell and Stokes 2004). Although predicted productivity rates of approximately $1 \mathrm{~g} \mathrm{C} \mathrm{m}^{-2}$ year $^{-1}$ are exceptionally low, hypolithic production provides an important food source for grazing nematodes and protozoans, therefore providing the basis for the survival of a whole ecosystem in an extreme environment (Thomas 2005; Cowan et al. 2014).

Four recent reviews with a focus on the microbial ecology of hypoliths are available (Chan et al. 2012; Pointing and Belnap 2012; Makhalanyane et al. 2014, 2015).

\section{Endoliths}

The mode of endolithic colonization depends primarily on the micromorphological and structural properties of the rock (Makhalanyane et al. 2014), where chasmoliths are found in surface cracks and endoliths inhabit the pore spaces between mineral grains, the depth of 
the endolithic community being dictated by the translucence of the mineral (Golubic et al. 1981; Nienow et al. 2003; B “u del et al. 2009). Cyanobacteria are the dominant colonists in these niches (Bu"del et al. 2009), although both bacterial and algal taxa may be present (Büdel et al. 2008). Early studies indicated that free-living cyanobacteria dominated en-dolithic communities (Friedmann et al. 1988). This was enhanced by a study on gypsum crusts on Alexander Island, west of the Antarctic Peninsula, where the presence of the cyanobacterium Chlorogloea sp. was shown (Hughes and Lawley 2003). Similarly, a recent study analysing gypsum crust endolithic communities in the Canadian High Arctic highlighted a predominance of phototrophic cyanobacteria $(21 \%$ of total bacterial py-rosequencing reads) with Nostoc sp., Loriellopsis sp. and Chroococcidiopsis sp. all rep-resented (Ziolkowski et al. 2013).

In the Antarctic Dry Valleys, a total of 17 cyanobacterial species have been identified in McMurdo Dry Valley endolithic communities where, depending on the dominant cyanobacterium, three communities types were identified: Gloeocapsa, HormathonemaGloeocapsa and Chroococcidiopsis (Friedmann et al. 1988). Other cyanobacteria morphologically similar to Gloeocapsa, Plectonema, and Hormathonema species have also been reported in Antarctica (de la Torre et al. 2003; de los Rios et al. 2004; de los Rios et al. 2005). Endoliths from the Taylor Valley contained several different genera of cyanobacteria, including Chroococcidiopsis, Cyanothece, and Nostoc species (Bu"del et al. 2008). Coarse-grained marbles from Nussbaum Riegel in the central Taylor Valley was dominated by Chroococcidiopsis (Bu"del et al. 2009). A culture-independent survey of McKelvey Valley endoliths reported that Chroococcidiopsis-like morphotypes dominated sandstone substrates (Pointing et al. 2009). A recent study of Miers Valley granite chasmoendoliths demonstrated that Leptolyngbya (Oscillatoriales) was the dominant cyanobacterial colonist (Yung et al. 2014). Interestingly, the authors reported a shift from Chroococcidiopsis-like phylotypes on colder-drier slopes to Synechococcus-like phylotypes on warmer-wetter slopes. A comparison between endolithic communities located in the Antarctic Dry Valleys $\left(76^{\circ} \mathrm{S}\right)$ and the Canadian High Arctic $\left(75^{\circ} \mathrm{S}\right)$ highlighted that although more extreme conditions (e.g. elevated UV radiation as a result of the depletion of the ozone column) prevail in the Antarctic, a higher level of cyanobacterial biodiversity is evident within the endolithic communities present when compared with High Arctic counterparts (Cockell et al. 2003). Precipitation-driven water flow through the rock and the more heterogeneous physical structure of the substrate was suggested to primarily account for the lower biodiversity in Arctic-based endoliths.

\section{Permafrost}

Estimates suggest that $25 \%$ of the northern hemisphere is underlain by permafrost (soil that has remained frozen for at least two consecutive years; reviewed in Jansson and Tas 2014) and may comprise up to $50 \%$ of subsurface organic carbon stocks (Frank-Fahle et al. 2014). The extent of permafrost distribution has decreased over the last century and it is predicted that near-surface permafrost thawing will be a continuous feature in the coming years as a feature of global warming (Steven et al. 2008). The microbial response to this permafrost thawing is still unresolved, including the contributions of particular microbial groups to $\mathrm{CO}_{2}$ and $\mathrm{CH}_{4}$ fluxes. Interestingly, cyanobacteria have been absent from numerous phylogenetic surveys using Arctic permafrost samples, with actinobacteria and proteobacteria predominating (Steven et al. 2008; Frank-Fahle et al. 2014). A metagenomic study also reported no cyanobacteria signature in a 2-m deep permafrost sample (Yergeau et al. 2010), although the possible detection of nitrogenase (nifH) 
belonging to cyanobacteria was proposed. The lack of cyanobacterial molecular signatures in Arctic permafrost is surprising and requires further examination.

In the high latitude Antarctic, the permafrost layer is typically within a few tens of $\mathrm{cm}$ from the soil surface (Cary et al. 2010) and is present beneath almost the entire ice-free area. The seasonal thawing of permafrost may be a source of moisture for the overlying active layer soils (Stomeo et al. 2012), although high altitude and latitude permafrosts may show limited (or no) seasonal thaw. Relatively few studies have investigated the bacterial diversity in Antarctic permafrosts. Drill cores from the McMurdo Dry Valleys (Gilichinsky et al. 2007) contained up to $10^{4}$ viable cells/g, ten times more than reported in Taylor Valley core samples (Bakermans et al. 2014). Cyanobacterial taxa were present in all core samples, but could not be cultivated. In a $4.2 \mathrm{~m}$ permafrost core from Deception Island, the microbial community showed a well-stratified distribution (Blanco et al. 2012), with cyanobacteria (Nostoc sp.) only present to a depth of 1.6-2.0 m. Cyanobacteria can ac-tively move in response to wetting or drying events by migrating towards or retreating from the soil surface (Garcia-Pichel and Pringault 2001). This behaviour, together with a tactic response to light, may explain the localized distribution of cyanobacteria in the permafrost matrix.

\section{Cryoconites}

Cryoconites are cylindrical cavities in the ice surfaces with a thin layer of sediment, often overlaid by water. Formation of these habitats is initiated through wind-blown dust gathering on small depressions that absorb solar radiation and the subsequent ablation of the surrounding ice (Wharton $\mathrm{Jr}$ et al. 1985; Podgorny and Grenfell 1996). This microenvironment plays an important role in glacial ecosystems with different boundaries, energy flow, and nutrient cycling. In these systems, sediment deposition is thought to promote microbial colonization, growth and succession (Mueller et al. 2001). They have been shown to act as refugia for microorganisms from harsh environments and are possibly important biomass seeding sources in Arctic regions and Antarctica. Their relevance in Antarctica, as seeding sources, could be related to the ice-free landmasses proximity and their thermodynamics constraints that make cryoconites development only possible within a few regions (Foreman et al. 2007).

Cyanobacteria can dominate microbial consortia formed in cryoconite glacier surfaces mainly represented by Phormidium, Nostoc, and especially species from the genus Leptolyngbya (Stibal et al. 2006; Cameron et al. 2012). These species are considered opportunistic organisms with wide ecological roles and strong colonizing potential, rather than glacial specialists. Although one $16 \mathrm{~S}$ rRNA gene-based clone library study suggested that cyanobacteria are not predominant bacterial members within High Arctic cryoconite holes (Edwards et al. 2011). A recent study employing deep sequencing showed that cyanobacteria, namely Microcoleus and Phormidium were the most abundant bacterial groups in cryoconite located in Svalbard located in the high Arctic (Edwards et al. 2011).

\section{Aquatic habitats}

Inland aquatic systems are widely distributed in continental Antarctica and parts of the Arctic. Early studies suggested that aquatic ecosystems in Antarctica contained low levels of cyanobacterial diversity. For example, only two cyanobacterial taxa, Phormidium frigidum and Lyngbya martensiana, were described in Lake Fryxell on the basis of microscopic observations (Wharton et al. 1983). However, 20 years later, the use of both $16 \mathrm{~S}$ 
rRNA genes and internal transcribed spacer (ITS) regions show an entirely different picture (Taton et al. 2003a). Fifteen phylotypes belonging to the genera Geitlerinema, Nostoc, Hydrocoryne, Leptolyngbya, Lyngbya, Pseudanabaena, Phormidium, Oscillatoria, Schizothrix and Nodularia were recorded in the microbial mats of Lake Fryxell in McMurdo Dry Valleys.

It is now accepted that life in these water bodies is essentially microbial. Indeed, microbes can reach very high levels at the bottom of lakes, ponds and streams where benthic mats and films are formed with layering structures responding to biogeochemical gradients (Vincent 2000; Rochera et al. 2013). Planktic organisms also play a relevant role in these ecosystems (Lizotte 2008). Filamentous cyanobacteria, namely heterocytous Nostocales and non-heterocystous Oscillatoriales are critical in structuring these microbial mats (Vincent 2000); although other microbes, such as diatoms (eukaryotes) and heterotrophic bacteria are also commonly found (Varin et al. 2012b; Stanish et al. 2013). In addition, cyanobacteria contribute significantly to the productivity in these ecosystems (Taton et al. 2003a; Koma'rek et al. 2008). This has been shown for Ace Lake in the Vestfold Hills region where cyanobacteria were proposed to contribute to primary production in the oxic zone of this lake with the genus Synechococcus well represented (Lauro et al. 2010; $\mathrm{Ng}$ et al. 2010). It is probable that its proximity to marine waters may have influenced the perseverance of Synechococcus spp. in the deep chlorophyll maximum (DCM) of Ace Lake (Laybourn-Parry and Bell 2014); which is one of the most important cyanobacteria in the global ocean ecosystem. This group is also present in a number of other lakes in the Vestfold Hills (Powell et al. 2005).

A molecular study targeting 16S rRNA genes in high Artic microbial mats has suggested the global distribution of low-temperature cyanobacterial ecotypes throughout the cold terrestrial biosphere (Jungblut et al. 2010). Cyanobacterial sequences were $>99 \%$ similar to sequences from Antarctica, including taxa previously assumed to be endemic to Antarctica, implying a lack of biogeographic patterns. However Nodularia, described regularly for Antarctic microbial mats, in particular in the McMurdo Ice Shelf, McMurdo Dry Valleys and Larsemann and Vestfold Hills (Taton et al. 2003a; Jungblut et al. 2005; Taton et al. 2006), was not found at any of the Arctic sites. These findings, as well as others (Papke et al. 2003; Verleyen et al. 2010; Bahl et al. 2011), suggest that cyanobacteria follow biogeographic patterns more typical of macroscopic organisms, and that both dispersal and/ or settlement limitation likely play important roles in explaining the distribution of cyanobacterial genotypes. In fact, the high morphological diversification of Phormidum autumnale, thriving in the Antarctic from Paleozoic times, suggests the coevolution of lineages and formation of complex associations, resulting in a specific endemic Antarctic cyanobacterial flora (Strunecky' et al. 2012).

An alternative explanation is that the biogeography of Antarctic cyanobacteria reflects the influence of environmental variation. Comparing five samples from four lakes spanning a range of different ecological environments in Larsemann Hills, Vestfold Hills and Rauer Islands, 17 morphospecies and 28 ribotypes belonging to the Oscillatoriales, Nostocales and Chroococcales were identified (Taton et al. 2006). Most cyanobacterial ribotypes (20 of 28) were unique to the respective sample and none of them were found in more than three samples. Interestingly, two samples (Heart and ReidJ), collected at the same depth $(\sim 4 \mathrm{~m})$, shared four OTUs not found in any other sample. Different cyanobacterial morphotype assemblages were also present in deep lakes and shallow ponds located in the Larsemann Hills and Bølingen Islands, East Antarctica (Sabbe et al. 2004). Filamentous Leptolyngbya dominated deep-water assemblages, while shallow-water assemblages were taxonomically more diverse, containing several members of the Oscillatoriales and Nostocales as 
the most characteristic taxa. Overall, these findings suggest depth and consequently light intensity as important factors in explaining the cyanobacterial com-munity composition observed (Sabbe et al. 2004; Taton et al. 2006). Other factors such as temperature fluctuation and exposure to freezing can also vary with depth.

The effect of environmental factors was also observed in a study conducted on 13 ponds formed after an original larger pond was drained by a crack in an ice dam from the McMurdo Ice Shelf (Sutherland 2009). Two years after their formation, the cyanobacterial population distribution varied greatly among the new ponds, whereas a great proportion (60 $\%)$ of the diatom species where shared among all ponds. Cyanobacterial community shifts were mainly driven by nitrate, Dissolved Organic Carbon (DOC), desiccation and conductivity (Sutherland 2009). Conductivity (a proxy for salinity) has been previously reported to be an important factor in shaping cyanobacterial assemblages in other Antarctic aquatic ecosystems, including Larsenman Hills, Prydz Bay and Ross Ice Shelf regions (Sabbe et al. 2004; Jungblut et al. 2005; Taton et al. 2006; Vyverman et al. 2010). In direct contrast, cyanobacterial communities did not separate well along the environmental gradients found in six ponds in the Pyramid Trough Wetland (Jungblut et al. 2012), as might be expected if community structure is determined by the environment (species sorting or habitat filtering). These random assembly patterns are better explained by neutral theories (Hubbell 2001) rather than niche-driven dynamics.

Cyanobacterial communities provide habitat and/or nutrition for other organisms including prokaryotes, eukaryotic phototrophs and eukaryotic heterotrophs (Cary et al. 2010). Therefore, it is possible that species interactions play a role in the assembly of microbial mat communities. Significant relationships were found between diatom communities, cyanobacterial and heterotrophic bacterial communities studying microbial co-occurrence patterns in mats from five Dry Valley streams (Stanish et al. 2013). Specifically, cyanobacteria showed a higher percentage of associations with members of the Acidobacteria, Deinococci, and Chloroflexi. However, co-occurrence does not necessarily imply an interaction. A tangible understanding of complex biological communities requires experimental verification of the strength, direction and reliability of large numbers of potential positive and negative biotic interactions, a goal not currently feasible (Koch 2012). Thus, many questions remain about the factors and processes shaping cyanobacterial community assembly in Antarctic aquatic ecosystems.

In freshwater bodies of the high Arctic, mainly in lakes, primary production is only nutrient limited in the Planktic communities, whereas the microenvironments of the cyanobacteria-dominated benthic mats have increased nutrient availability and sufficiency (Vezina and Vincent 1997; Bonilla et al. 2005) showed that in the lakes, ponds and streams of Bylot Island, picoplanktic Synechococcus sp. were dominant in the Planktic fraction but the benthos was dominated by the filamentous oscillatoriacean strains. Arctic microbial mats usually show a surface layer with higher density of cells with higher accumulation of mineral precipitates underneath.

Factors such as habitat stability (Varin et al. 2012b), as well as the interactions and activities that occur within (Tolker-Nielsen and Molin 2000), could generate the structural and compositional differences observed between lake and stream microbial mats. The physical heterogeneity intrinsic to streams and temporal heterogeneity in flow has been suggested as the cause of species accumulation and diversification and explains the coexistence of species with diverse adaptations and requirements in stream phototrophic biofilms (Larson and Passy 2013). Highly pigmented cyanobacterial colonies are conspicuous in stream mats, which could be related to the more stressful conditions occurring in these habitats subjected to frequent desiccation processes and periods with direct 
exposure to solar UV and PAR radiation, where some cyanobacterial taxa may have physiological advantages to cope with such environmental conditions (Gan et al. 2014). Nevertheless, the development of a consistent Dichothrix superficial gelatinous film only in lake microbial mats could be related to the higher stability of this habitat (de los Rios et al. 2014). In turn, the presence of this dense film containing microbial cells and compact calcium carbonate precipitates probably induces the formation of specific microenvironments within lake mats. In fact the upper layer could modify the light reaching the rest of the organisms and consequently the conditions for determining cyanobacterial composition and the spatial distribution under the upper layer (Oppenheim and Paterson 1990; Petroff et al. 2010). The lower water availability could also be determining factors in Chroococcales and Nostocales composition found in flowing water ecosystems.

\section{Functional roles of Arctic and Antarctic cyanobacteria}

Current evidence suggests that both Arctic and Antarctic cyanobacteria are essential to various ecosystem processes (Wynn-Williams 1996a; Cowan et al. 2011; Strauss et al. 2012; Chan et al. 2013). The rise in surface temperatures in some regions is likely to lead to alterations, which may change the community dynamics in Polar habitats. One immediate effect is the increase in cyanobacterial blooms within lakes as a consequence of warmer waters and the increased nutrient input from catchments (Wagner and Adrian 2009). Understanding cyanobacterial functionality is thus crucial to predicting in what way global changes might affect key biogeochemical processes mediated by microbes. Polar habitats may represent excellent model systems for investigating how physical and chemical thresholds will be affected by climate change. While the relationship between microbial diversity and functional redundancy is far from certain, it is reasonable to expect that a decrease in diversity will affect functionality. Recent evidence from studies in other soil systems suggests that even moderate losses in microbial diversity may compromise functionality (Philippot et al. 2013; Singh et al. 2014).

\section{Nitrogen cycling}

Recently, it has been shown that climate change is likely to affect nitrogen-fixing microorganisms in general and cyanobacteria in particular (Singh et al. 2010; Santos et al. 2014). Through the application of modern molecular phylogenetic approaches, we are beginning to better understand microbial functionality in Polar Regions. When the results of these studies are taken together it becomes clear that cyanobacteria are central in this environment (Ferna'ndez-Valiente et al. 2001).

The first environmental microarray analysis of Antarctic soil communities found that cyanobacteria increased with increasing latitude (Yergeau et al. 2008). This study demonstrated a robust connection between community structure and functional gene distribution in Antarctic soils. Principal coordinate analysis showed a relationship between cyanobacteria and genes for nitric oxide reductase (norB) (Yergeau et al. 2008). These genes have previously been identified in the genome of the non-denitrifying cyanobacterium Synechocystis sp. strain PCC6803 (Busch et al. 2002). Surprisingly, the study by Yergeau et al. (2008) does not appear to show a strong relationship between cyanobacteria and genes implicated in nitrogen fixation (nif $\mathrm{H})$, ammonium oxidizing bacteria (amo $\mathrm{A})$, and other genes associated with nitrogen cycling (nar, nos, nas). These genes appear, at least in soil bacteria from the Peninsula, to show stronger relationships with Proteobacteria and Chloroflexi. However, in a similar study undertaken on Arctic permafrost, 
cyanobacteria-mediated nitrogen fixation was suggested through the identification of a single type of nitrogenase (nifH) (Yergeau et al. 2010).

A recent study by Chan et al. (2013), also used microarray-based technologies to assess terrestrial microbes from the McKelvey Valley. This study found genes implicated in major pathways of the nitrogen cycle and showed nitrogen input driven by Cyanobacteria together with other bacteria. This study also reported that cyanobacteria were one of the most abundant nitrifiers. Interestingly, the potential for soil nitrate removal through denitrification was shown to be influenced more by Bacteroidetes and Deltaproteobacteria (Chan et al. 2013). The study demonstrates the importance of lithobionts for nutrient input in these extremely oligotrophic environments.

Cyanobacteria also appear to drive nitrogen fixation in moist soil communities (Niederberger et al. 2012). For instance, it has been shown that the $\mathrm{N}_{2}$-fixation activity of cyanobacteria in Arctic regions is primarily governed by moisture gradients associated with topography that determines nutrient availability (Stewart et al. 2014). A study by Niederberger et al. (2012) used cDNA clone library construction of nifH genes, quantitative PCR, fingerprinting analysis, and nitrogenase assays to profile ephemerally wetted soils from Miers Valley. The authors reported nitrogen fixation rates, which ranged from undetectable to maxima approximating $5.8 \mathrm{nmol} \mathrm{Ncm}^{-3} \mathrm{~h}^{-1}$ from hyporheic sites to lower values ranging from 0.04 to $5.8 \mathrm{nmol} \mathrm{N} \mathrm{cm}{ }^{-3} \mathrm{~h}^{-1}$ in arid sites. Noteworthy was the dominance of cyanobacterial signatures from cDNA samples (81.6\% of the clone library). The results of this study are in agreement with previous findings implicating cyanobacteria as major input sources of nitrogen in Antarctic soils (Cowan et al. 2011).

Benhua et al. (2014) recently assessed biogeochemical responses to nutrient, moisture and temperature manipulations on soil from Signy Island and South Orkney Islands in the Maritime Antarctic. The authors conclude that increments in temperature, water availability, and organic compounds will probably increase soil microbial activity leading to more rapid nitrogen and carbon cycling. This is anticipated to have a positive feedback on biogeochemical cycling especially where or when these factors act in concert (Benhua et al. 2014).

\section{Carbon fixation}

Cyanobacteria as a globally dominant photoautotrophic lineage are thought to be particularly important in Antarctic carbon cycling. However, using metagenomics Pearce et al. (2012) reported cyanobacteria being underrepresented in southern maritime Antarctic soil, with only $3.4 \%$ of total sequences belonging to this phylum, although $\sim 1 \%$ of the genes identified were involved in $\mathrm{CO}_{2}$ fixation. This result is surprising and may be a localized phenomenon, rather than representative of all southern maritime Antarctic soils. In any event, cyanobacteria have been shown to use a number of methods in order to increase photosynthesis (Rae et al. 2013). For example, they are able to produce carboxysomes, which together with $\mathrm{CO}_{2}$-concentrating mechanisms (CCM) augment the chemical conditions in the locality of the primary $\mathrm{CO}_{2}$-fixing enzyme (D-ribulose 1,5-bisphosphate carboxylase/oxygenase (RubisCO)), resulting in increased photosynthesis (Rae et al. 2013). In Antarctic habitats such mechanisms are essential for nutrient input.

Chan et al. (2013) recently reported the presence of key carbon cycling genes such as RubisCO, the propionyl-CoA/acetyl-CoA carboxylase ( $p c c)$, and the carbon monoxide dehydrogenase $(\mathrm{CODH})$ in the reductive acetyl-CoA pathway, all of which are essential for sequestering carbon. The authors assigned possession of Functional Form I RubisCO as suggestive of photoautotrophic potential, and was largely attributed to cyanobacteria (Chan 
et al. 2013). Interestingly, Functional Forms II and III RubisCO were assigned to other groups including Archaea, Actinobacteria and Proteobacteria, known chemolithotrophs.

The cyanobacterium, Nostoc commune, is a prominent primary producer in continental Antarctica and has been used as a model for elucidating the ecological constraints on total carbon fixation particularly for ice-free areas (Novis et al. 2007). This study used laboratory experiments in order to investigate the effects of incident irradiance, tem-perature, and desiccation on Nostoc commune. The gathered data, when coupled with previously published data and field measurements of carbon fixation, allowed the authors to estimate annual net carbon fixation to be within the range 14.5-21.0 g C fixed $\mathrm{m}^{-2}$ Nostoc mat, depending on year/season. Estimates correlated with accumulated hours above $0{ }^{\circ} \mathrm{C}$ during the year (thermal time), suggesting that there may be a trade-off between the ability to exploit short phases of higher temperature and the efficient utilization of lower irradiance at low temperature (Novis et al. 2007).

While evidence of genes implicated in functional processes is in of itself remarkable, given the extreme conditions of the Antarctic, it is important to assess how soil communities (cyanobacteria in particular) might react to increased levels of carbon and nitrogen. A simple yet elegant experiment by Hopkins et al. (2008) assessed the impact of additions of carbon and nitrogen on the structure and activity of microbial communities. In this study the rates of $\mathrm{CO}_{2}$ production were measured along with enzymatic activities (dehydroge-nase, $\beta$ glucosidase, acid and alkaline phosphatase and arylsulphatase). When normalized with respect to soil respiration, only arylsulphatase per unit of respiration showed a sig-nificant increase with $\mathrm{C}$ and $\mathrm{N}$ additions, while no evidence of changes in the microbial community structure was found as a result of the $\mathrm{C}$ and $\mathrm{N}$ supplementation treatments (Hopkins et al. 2008). Primary productivity in Antarctic soils is reviewed comprehensively by Hopkins et al. (2014).

\section{Cyanobacterial toxins}

Temperate cyanobacteria produce a range of natural toxins collectively known as cyanotoxins (Quiblier et al. 2013; Moreira et al. 2014), whose production may be directly influenced by environmental conditions (Neilan et al. 2013). However, very little is known regarding the toxins produced by cyanobacteria in Arctic and Antarctic lakes, ponds or even terrestrial environments. A study by Wood et al. (2008a) assessed microcystin (MC), the largest and most structurally diverse group of cyanobacterial toxins, production and cyanobacterial community structure of Antarctic microbial mat samples. This study identified Nostoc sp. as a MC producer using amplification of the mcyE gene (Wood et al. 2008a). A variant of MC, as well as the neurotoxin saxitoxin (STX), has also been detected in cyanobacterial communities in the Arctic (Kleinteich et al. 2012). The levels of MC detected were comparable to those found in the Antarctic (1-15,900 $\mu \mathrm{g} \mathrm{MC} / \mathrm{kg}$ dry weight). A more recent study by Kleinteich et al. (2014) reported cyanotoxins MC being detected in 26 of the 27 mats dominated by Leptolyngbya and Phormidium. The authors also confirmed, for the first time, evidence of cylindrospermopsin through liquid chro-matography-mass spectrometry and amplification of the coding genes cyrAB and cyrJ. How changing climate is likely to influence the production of cyanotoxins remains scantily understood. However, Kleinteich et al. (2012) showed that temperature shifts to $8-16^{\circ} \mathrm{C}$, which are potentially reached during summer months in polar areas, might affect cyanobacterial diversity, and in some cases result in shifts to toxin-producing species. These findings suggest that elevated toxin concentrations may drastically change fresh-water polar ecosystems (Kleinteich et al. 2012). 
Given the fact that several fatalities have been reported due to acute MC poisoning (Jochimsen et al. 1998), it is important to understand the effects of global change on MC concentrations. It has been shown through batch culture experiments that high MC production in cyanobacteria is directly correlated to high nitrogen and phosphorus concentration. Desert soils have been reported to contribute to dust-mediated impacts (e.g. by means of atmospheric nutrient deposition) at regional scales (Pointing and Belnap 2014), and it cannot be assumed that the effects may not be global.

\section{Responses and adaptations to extreme environments}

In general, temperature and water availability are thought to be the most important determinants of microbial diversity and community structure in cold environments (Cary et al. 2010). At low temperatures, proteins are less flexible and are susceptible to denaturation, cell membranes often lose their fluidity, which affects nutrient transport, and nucleic acids are more stable, resulting in inhibition of replication, transcription and translation (D'Amico et al. 2006).

Cyanobacteria have evolved several strategies to survive freezing and desiccation. These include entering a dormant state with low metabolic activity (Vincent et al. 2004). In Antarctica, freeze-dried mats have been shown to resume photosynthesis and other physiological processes within minutes to hours after re-thawing (Seckbach and Oren 2010). They produce specialized proteins (e.g. cold-shock proteins, antifreeze proteins) or other molecules (e.g. glycine betaine, EPS) that enable the cells to survive. Cold-adapted cyanobacteria also increase the production of unsaturated fatty acids to maintain membrane fluidity (Los and Mironov 2013) and DEAD-box RNA helicases (Rocak and Linder 2004), which aid in the maintenance of cellular processes despite the thermodynamic constraints. A metagenomic analysis of stress genes in microbial mat communities from Antarctica and the high Arctic has revealed genes coding for functional responses to environmental stress: the alternative sigma factor (sigma B), EPS, cold-shock proteins and membrane modifications (Varin et al. 2012a). A more extensive review on the tolerance of Cyanobacteria to cold can be found elsewhere (Vincent 2007).

Warming has also been shown to influence the size and composition of Cyanobacteria in soil. A study which deployed screens over soils at Signy Island in the South Orkney Islands reported an increase in the abundance of Cyanobacteria by 2-17 fold with substantial increases in the biomass of Phormidium and Nostoc spp. in warmed soils (Wynn-Williams 1996b). A recent study by Dennis et al. (2013) concluded that warming may constrain bacterial community responses to nutrient addition in some maritime Antarctic soils (southern) but not others (northern). This is contrary to the earlier view that Cyanobacteria (and eubacteria) may respond positively to environmental warming (Wynn-Williams 1996b; Yergeau et al. 2012).

\section{Conclusions}

We currently have no understanding on whether cyanobacterial communities will follow the same patterns as other organisms in response to changing climates. In Antarctic habitats cyanobacteria are crucial mediators of biogeochemical cycles, therefore elucidating their responses to changing climate would be a worthy feat for future studies. It has been proposed that changes in climate are likely to alter the ecological strategies of soil bacteria 
(Evans and Wallenstein 2014). Predicting the direct effects on Antarctic habitats, which are subject to climate changes, requires further research.

There have recently been new technical advancements, which may assist in understanding cyanobacterial adaptations in Polar environments. For instance, single cell genomics, may allow sequencing of bacterial genomes and 'viromes' from Arctic and Antarctic environments. There are currently no available cyanobacterial genomes from Arctic and Antarctic habitats, although we are aware of two draft genomes of isolates from Antarctic cyanobacterial mats (Pinnaka et al. 2013; Reddy et al. 2013). Such genome data may be crucial in revealing mechanistic insights of polar cyanobacterial isolates as has been done very recently with other phyla (Adriaenssens et al. 2014; Ferreras et al. 2014; Guerrero et al. 2014; Ronca et al. 2015). There is also a general lack of publicly available cyanobacterial virome data, which may lead to poor representation and potential underestimation of cyanophages in Antarctic environments (Zablocki et al. 2014). This deficit negatively affects our understanding of intra- and interspecies interactions.

Studies which target the products of transcription are now more feasible, and may provide insights into cyanobacterial metabolism in depauperate environments (JohnsonRollings et al. 2014). For instance, a recent study has assessed the effect of elevated temperatures on proteomic responses of individual organisms within a biofilm community (Mosier et al. 2014). An application of these methods would produce insights into cyanobacteria in cryptic niches. Taken together this data may be crucial in providing mechanistic insights of cyanobacterial adaptations.

We further propose expansion and extension of isotope approaches, which have been used in both High Arctic and Antarctic environments previously (Hopkins et al. 2009; Lyons et al. 2013), in order to shed light on the biogeochemical responses of Arctic and Antarctic cyanobacteria. Simulation studies, testing how changes in atmospheric $\mathrm{CO}_{2}$ and temperature affect cyanobacterial populations, would help us to understand how these phyla may evolve in situ. Altogether this data would help us to elucidate how the ecology, biogeochemistry and diversity of cyanobacteria may change as a response to environmental changes.

Acknowledgments We wish to gratefully acknowledge the University of Pretoria Research Development Program (TPM), Genomics Research Institute, The National Research Foundation (NRF) of South Africa's National Antarctic Program (SANAP program) (TPM, AV, EG. MWVG, DAC) and Ministerio de Economía y Competitividad (Spain): Grant ref CTM 2011-28736 (DV, AQ) for funding. We also wish to express our gratitude to Antarctica New Zealand for providing logistics support for our Antarctic research and Prof Craig Cary (University of Waikato NZTABS program) for facilitating access to Antarctica.

Conflict of interest The authors declare no conflict of interest.

\section{References}

Adriaenssens EM, Guerrero LD, Makhalanyan TP, Aislabie JM, Cowan DA (2014) Draft genome sequence of the aromatic hydrocarbon-degrading bacterium Sphingobium sp. Strain Ant17, isolated from Antarctic soil. Genom Announc. doi:10.1128/genomeA.00212-14

Agawin NS, Agusti S (1997) Abundance, frequency of dividing cells and growth rates of Synechococcus sp. (cyanobacteria) in the stratified Northwest Mediterranean Sea. J Plankton Res 19:1599-1615

Aislabie JM, Chhour K-L, Saul DJ, Miyauchi S, Ayton J, Paetzold RF, Balks MR (2006) Dominant bacteria in soils of Marble Point and Wright Valley, Victoria Land, Antarctica. Soil Biol Biochem 38:3041-3056. doi:10.1016/j.soilbio.2006.02.018

Aislabie J, Jordan S, Barker G (2008) Relation between soil classification and bacterial diversity in soils of the Ross Sea region, Antarctica. Geoderma 144:9-20 
Babalola OO, Kirby BM, Le Roes-Hill M, Cook AE, Cary SC, Burton SG, Cowan DA (2009) Phylogenetic analysis of actinobacterial populations associated with Antarctic Dry Valley mineral soils. Environ Microbiol 11:566-576. doi:10.1111/j.1462-2920.2008.01809.x

Bahl J et al (2011) Ancient origins determine global biogeography of hot and cold desert cyanobacteria. Nat Commun 2:163. doi:10.1038/ncomms 1167

Bakermans C, Skidmore ML, Douglas S, McKay CP (2014) Molecular characterization of bacteria from permafrost of the Taylor Valley, Antarctica. FEMS Microbiol Ecol 89(2):331-346

Belnap J (2003) The world at your feet: desert biological soil crusts. Front Ecol Environ 1:181-189

Belnap J, Gardner JS (1993) Soil microstructure in soils of the Colorado Plateau: the role of the cyanobacterium Microcoleus vaginatus. West N Am Nat 53:40-47

Belnap J, Lange OL (2002) Biological soil crusts: structure, function, and management; with 30 tables, vol 150. Springer, Berlin

Benhua S et al (2014) Biogeochemical responses to nutrient, moisture and temperature manipulations of soil from Signy Island, South Orkney Islands in the Maritime Antarctic. Antarct Sci 26(5):513-520

Blanco Y et al (2012) Prokaryotic communities and operating metabolisms in the surface and the permafrost of Deception Island (Antarctica). Environ Microbiol 14:2495-2510. doi:10.1111/j.1462-2920.2012. 02767.x

Bockheim JG, McLeod M (2008) Soil distribution in the McMurdo Dry Valleys, Antarctica. Geoderma 144:43-49

Bonilla S, Villeneuve V, Vincent WF (2005) Benthic and planktonic algal communities in a high arctic lake: pigment structure and contrasting responses to nutrient enrichment. J Phycol 41:1120-1130

Bottos EM, Vincent WF, Greer CW, Whyte LG (2008) Prokaryotic diversity of arctic ice shelf microbial mats. Environ Microbiol 10:950-966

Bowker MA, Maestre FT, Eldridge D, Belnap J, Castillo-Monroy A, Escolar C, Soliveres S (2014) Biological soil crusts (biocrusts) as a model system in community, landscape and ecosystem ecology. Biodivers Conserv 23:1619-1637

Büdel B, Colesie C (2014) Biological soil crusts. Antarctic terrestrial microbiology. Springer, Berlin, pp 131-161

Büdel B, Bendix J, Bicker FR, Allan Green T (2008) Dewfall as a water source frequently activates the endolithic cyanobacterial communities in the granites of Taylor Valley, Antarctica. J Phycol $44: 1415-1424$

Büdel B et al (2014) Improved appreciation of the functioning and importance of biological soil crusts in Europe: the Soil Crust International Project (SCIN). Biodivers Conserv 23(7):1619-1637

Büdel B, Schulz B, Reichenberger H, Bicker F, Green T (2009) Cryptoendolithic cyanobacteria from calcite marble rock ridges, Taylor Valley, Antarctica. Algol Stud 129:61-69

Busch A, Friedrich B, Cramm R (2002) Characterization of the norB gene, encoding nitric oxide reductase, in the nondenitrifying cyanobacterium Synechocystis sp. strain PCC6803. Appl Environ Microbiol 68:668-672

Cameron KA, Hodson AJ, Osborn AM (2012) Structure and diversity of bacterial, eukaryotic and archaeal communities in glacial cryoconite holes from the Arctic and the Antarctic. FEMS Microbiol Ecol 82:254-267. doi:10.1111/j.1574-6941.2011.01277.x

Cary SC, McDonald IR, Barrett JE, Cowan DA (2010) On the rocks: the microbiology of Antarctic Dry Valley soils. Nat Rev Microbiol 8:129-138. doi:10.1038/nrmicro2281

Castenholz RW (1988) Culturing methods for cyanobacteria. Methods Enzymol 167:68-93

Castillo-Monroy AP, Maestre FT, Delgado-Baquerizo M, Gallardo A (2010) Biological soil crusts modulate nitrogen availability in semi-arid ecosystems: insights from a Mediterranean grassland. Plant Soil 333:21-34

Krembs C, Eicken H, Junge K, Deming J (2002) High concentrations of exopolymeric substances in Arctic winter sea ice: implications for the polar ocean carbon cycle and cryoprotection of diatoms. Deep Sea Res Part I 49:2163-2181

Chan Y et al (2012) Hypolithic microbial communities: between a rock and a hard place. Environ Microbiol 14:2272-2282. doi:10.1111/j.1462-2920.2012.02821.x

Chan Y, Van Nostrand JD, Zhou J, Pointing SB, Farrell RL (2013) Functional ecology of an Antarctic Dry Valley. Proc Natl Acad Sci. doi:10.1073/pnas.1300643110

Cockell CS, Stokes MD (2004) Ecology: widespread colonization by polar hypoliths. Nature 431:414-414. http://www.nature.com/nature/journal/v431/n7007/suppinfo/431414a_S1.html

Cockell C, Rettberg P, Horneck G, Scherer K, Stokes DM (2003) Measurements of microbial protection from ultraviolet radiation in polar terrestrial microhabitats. Polar Biol 26:62-69

Convey P et al (2014) The spatial structure of Antarctic biodiversity. Ecol Monogr 84:203-244. doi:10. $1890 / 12-2216.1$ 
Cowan DA, Ah Tow LA (2004) Endangered antarctic environments. Annu Rev Microbiol 58:649-690. doi:10.1146/annurev.micro.57.030502.090811

Cowan DA, Khan N, Pointing SB, Cary SC (2010) Diverse hypolithic refuge communities in the McMurdo Dry Valleys. Antarct Sci 22:714-720. doi:10.1017/s0954102010000507

Cowan DA, Sohm JA, Makhalanyane TP, Capone DG, Green TGA, Cary SC, Tuffin IM (2011) Hypolithic communities: important nitrogen sources in Antarctic desert soils. Environ Microbiol Rep 3:581-586. doi:10.1111/j.1758-2229.2011.00266.x

Cowan DA, Makhalanyane TP, Dennis PG, Hopkins DW (2014) Microbial ecology and biogeochemistry of continental Antarctic soils. Front Microbiol 5:154. doi:10.3389/fmicb.2014.00154

Curtis T (2006) Microbial ecologists: it's time to'go large'. Nat Rev Microbiol 4:488

D’Amico S, Collins T, Marx JC, Feller G, Gerday C (2006) Psychrophilic microorganisms: challenges for life. EMBO Rep 7:385-389

de la Torre JR, Goebel BM, Friedmann EI, Pace NR (2003) Microbial Diversity of Cryptoendolithic Communities from the McMurdo Dry Valleys, Antarctica. Appl Environ Microbiol 69:3858-3867. doi:10.1128/aem.69.7.3858-3867.2003

de los Rios A, Wierzchos J, Sancho LG, Ascaso C (2004) Exploring the physiological state of continental Antarctic endolithic microorganisms by microscopy. FEMS Microbiol Ecol 50:143-152. doi:10.1016/j. femsec.2004.06.010

de los Rios A, Sancho LG, Grube M, Wierzchos J, Ascaso C (2005) Endolithic growth of two Lecidea lichens in granite from continental Antarctica detected by molecular and microscopy techniques. New Phytol 165:181-190

de los Rios A, Cary C, Cowan D (2014) The spatial structures of hypolithic communities in the Dry Valleys of East Antarctica. Polar Biol. doi:10.1007/s00300-014-1564-0

Dennis PG, Newsham KK, Rushton SP, Ord VJ, O’Donnell AG, Hopkins DW (2013) Warming constrains bacterial community responses to nutrient inputs in a southern, but not northern, maritime Antarctic soil. Soil Biol Biochem 57:248-255. doi:10.1016/j.soilbio.2012.07.009

Dupraz C, Reid RP, Braissant O, Decho AW, Norman RS, Visscher PT (2009) Processes of carbonate precipitation in modern microbial mats. Earth-Sci Rev 96:141-162

Edwards A et al (2011) Possible interactions between bacterial diversity, microbial activity and supraglacial hydrology of cryoconite holes in Svalbard. ISME J 5:150-160. doi:10.1038/ismej.2010.100

Escolar C, Martínez I, Bowker MA, Maestre FT (2012) Warming reduces the growth and diversity of biological soil crusts in a semi-arid environment: implications for ecosystem structure and functioning. Philos Trans R Soc B 367:3087-3099

Evans SE, Wallenstein MD (2014) Climate change alters ecological strategies of soil bacteria. Ecol Lett 17:155-164. doi:10.1111/ele.12206

Fernández A, Mouriño-Carballido B, Bode A, Varela M, Marañón E (2010) Latitudinal distribution of Trichodesmium spp. and $\mathrm{N}_{2}$ fixation in the Atlantic Ocean. Biogeosci Discuss 7:2195-2225

Fernández-Valiente E, Quesada A, Howard-Williams C, Hawes I (2001) N2-fixation in cyanobacterial mats from ponds on the McMurdo Ice Shelf, Antarctica. Microb Ecol 42:338-349

Ferreras ER, De Maayer P, Makhalanyane TP, Guerrero LD, Aislabie JM, Cowan DA (2014) Draft genome sequence of Microbacterium sp. strain $\mathrm{CH} 12 \mathrm{i}$, isolated from shallow groundwater in Cape Hallett, Antarctica. Genom Announc 2:e00789

Fierer N, Jackson RB (2006) The diversity and biogeography of soil bacterial communities. Proc Natl Acad Sci USA 103:626-631. doi:10.1073/pnas.0507535103

Fierer N, Schimel JP, Holden PA (2003) Influence of drying-rewetting frequency on soil bacterial community structure. Microb Ecol 45:63-71. doi:10.1007/s00248-002-1007-2

Foreman CM, Sattler B, Mikucki JA, Porazinska DL, Priscu JC (2007) Metabolic activity and diversity of cryoconites in the Taylor Valley. Antarct J Geophys Res 2005-2012:112

Frank-Fahle BA, Yergeau É, Greer CW, Lantuit H, Wagner D (2014) Microbial functional potential and community composition in permafrost-affected soils of the NW Canadian Arctic. PLoS One 9:e84761

Friedmann EI, Hua M, Ocampo-Friedmann R (1988) Cryptoendolithic lichen and cyanobacterial communities of the Ross Desert. Antarct Polarforschung 58:251-259

Gan F, Zhang S, Rockwell NC, Martin SS, Lagarias JC, Bryant DA (2014) Extensive remodeling of a cyanobacterial photosynthetic apparatus in far-red light. Science 345:1312-1317

Garcia-Pichel F, Pringault O (2001) Microbiology-Cyanobacteria track water in desert soils. Nature 413:380-381. doi:10.1038/35096640

Garcia-Pichel F, Loza V, Marusenko Y, Mateo P, Potrafka RM (2013) Temperature drives the continentalscale distribution of key microbes in topsoil communities. Science 340:1574-1577

Gilichinsky D et al (2007) Microbial populations in Antarctic permafrost: biodiversity, state, age, and implication for astrobiology. Astrobiology 7:275-311 
Golubic S, Friedmann I, Schneider J (1981) The lithobiontic ecological niche, with special reference to microorganisms. J Sediment Res 51:475-478

Guerrero LD, Makhalanyane TP, Aislabie JM, Cowan DA (2014) Draft Genome Sequence of Williamsia sp. Strain D3, Isolated From the Darwin Mountains, Antarctica. Genom Announc doi:10.1128/genomeA.01230-13

Harding T, Jungblut AD, Lovejoy C, Vincent WF (2011) Microbes in high arctic snow and implications for the cold biosphere. Appl Environ Microbiol 77:3234-3243. doi:10.1128/AEM.02611-10

Hopkins DW et al (2008) Enzymatic activities and microbial communities in an Antarctic dry valley soil: Responses to C and N supplementation. Soil Biol Biochem 40:2130-2136. doi:10.1016/j.soilbio.2008. 03.022

Hopkins DW et al (2009) Isotopic evidence for the provenance and turnover of organic carbon by soil microorganisms in the Antarctic dry valleys. Environ Microbiol 11:597-608. doi:10.1111/j.1462-2920. 2008.01830.x

Hopkins D, Newsham K, Dungait J (2014) Primary production and links to carbon cycling in Antarctic soils. Antarctic Terrestrial Microbiology. Springer, Berlin, pp 233-248

Hubbell SP (2001) The unified neutral theory of biodiversity and biogeography. Princeton University Press, Princeton

Hughes KA, Lawley B (2003) A novel Antarctic microbial endolithic community within gypsum crusts. Environ Microbiol 5:555-565

Jansson JK, Taş N (2014) The microbial ecology of permafrost. Nat Rev Microbiol 6:414-425

Jochimsen EM et al (1998) Liver failure and death after exposure to microcystins at a hemodialysis center in Brazil. N Engl J Med 338:873-878

Johnson-Rollings AS et al (2014) Exploring the functional soil-microbe interface and exoenzymes through soil metaexoproteomics. ISME J. doi:10.1038/ismej.2014.130

Jungblut AD, Hawes I, Mountfort D, Hitzfeld B, Dietrich DR, Burns BP, Neilan BA (2005) Diversity within cyanobacterial mat communities in variable salinity meltwater ponds of McMurdo Ice Shelf, Antarctica. Environ Microbiol 7:519-529. doi:10.1111/j.1462-2920.2005.00717.x

Jungblut AD, Lovejoy C, Vincent WF (2010) Global distribution of cyanobacterial ecotypes in the cold biosphere. ISME J 4:191-202. doi:10.1038/ismej.2009.113

Jungblut AD, Wood SA, Hawes I, Webster-Brown J, Harris C (2012) The Pyramid Trough Wetland: environmental and biological diversity in a newly created Antarctic protected area. FEMS Microbiol Ecol 82:356-366

Kaštovská K, Elster J, Stibal M, Šantrůčková H (2005) Microbial assemblages in soil microbial succession after glacial retreat in Svalbard (High Arctic). Microb Ecol 50:396-407

Khan N, Tuffin M, Stafford W, Cary C, Lacap DC, Pointing SB, Cowan D (2011) Hypolithic microbial communities of quartz rocks from Miers Valley, McMurdo Dry Valleys, Antarctica. Polar Biol 34:1657-1668. doi:10.1007/s00300-011-1061-7

Kimble J (2004) Cryosols: permafrost-affected soils. Springer Science, Berlin

Kleinteich J, Wood SA, Küpper FC, Camacho A, Quesada A, Frickey T, Dietrich DR (2012) Temperaturerelated changes in polar cyanobacterial mat diversity and toxin production Nature. Clim Change 2:356-360

Kleinteich J et al (2014) Diversity of toxin and non-toxin containing cyanobacterial mats of meltwater ponds on the Antarctic Peninsula: a pyrosequencing approach. Antarct Sci FirstView. doi:10.1017/ S0954102014000145

Koch C (2012) Modular biological complexity. Science 337:531-532

Komárek O, Komárek J (2010) Diversity and Ecology of Cyanobacterial Microflora of Antarctic Seepage Habitats: comparison of King George Island, Shetland Islands, and James Ross Island, NW Weddell Sea, Antarctica. Microbial Mats. Springer, Berlin, pp 515-539

Komárek J, Elster J, Komárek O (2008) Diversity of the cyanobacterial microflora of the northern part of James Ross Island, NW Weddell Sea, Antarctica. Polar Biol 31:853-865

Larson CA, Passy SI (2013) Rates of species accumulation and taxonomic diversification during phototrophic biofilm development are controlled by both nutrient supply and current velocity. Appl Environ Microbiol 79:2054-2060

Lauro FM et al (2010) An integrative study of a meromictic lake ecosystem in Antarctica. Isme J 5:879-895

Laybourn-Parry J, Bell EM (2014) Ace Lake: three decades of research on a meromictic, Antarctic lake. Polar Biol 37:1685-1699

Lee CK, Barbier BA, Bottos EM, McDonald IR, Cary SC (2012) The inter-valley soil comparative survey: the ecology of Dry Valley edaphic microbial communities. ISME J 6:1046-1057. doi:10.1038/ismej. 2011.170 
Ling HU, Seppelt RD (1998) Non-marine algae and cyanobacteria of the Windmill Islands region, Antarctica with descriptions of two new species. Archiv für Hydrobiol 124:49-62

Lizotte MP (2008) Phytoplankton and primary production Polar lakes and rivers. Oxford University Press, Oxford, pp 157-178

Los D, Mironov K (2013) Membrane properties and cold stress responses in cyanobacteria and plants. FEBS Journal. Wiley, Hoboken, p 224

Lyons WB, Leslie DL, Harmon RS, Neumann K, Welch KA, Bisson KM, McKnight DM (2013) The carbon stable isotope biogeochemistry of streams, Taylor Valley, Antarctica. Appl Geochem 32:26-36. doi:10.1016/j.apgeochem.2012.08.019

Maestre FT et al (2013) Changes in biocrust cover drive carbon cycle responses to climate change in drylands. Global Change Biol 19:3835-3847

Makhalanyane TP, Valverde A, Birkeland N-K, Cary SC, Marla Tuffin I, Cowan DA (2013a) Evidence for successional development in Antarctic hypolithic bacterial communities. Isme J 7:2080-2090. doi:10. 1038/ismej.2013.94

Makhalanyane TP, Valverde A, Lacap DC, Pointing SB, Tuffin MI, Cowan DA (2013b) Evidence of species recruitment and development of hot desert hypolithic communities. Environ Microbiol Rep 5:219-224. doi:10.1111/1758-2229.12003

Makhalanyane TP, Pointing SB, Cowan DA (2014) Lithobionts: cryptic and refuge niches. In: Cowan DA (ed) Antarctic terrestrial microbiology: physical and biological properties of Antarctic soils. Springer, Berlin, pp 163-179

Makhalanyane TP, Valverde A, Gunnigle E, Frossard A, Ramond JB, Cowan DA (2015) Microbial ecology of hot desert edaphic systems. FEMS Microbiol Rev. doi:10.1093/femsre/fuu011

Moreira C, Ramos V, Azevedo J, Vasconcelos V (2014) Methods to detect cyanobacteria and their toxins in the environment. Appl Microbiol Biotechnol 98:8073-8082

Mosier AC, Li Z, Thomas BC, Hettich RL, Pan C, Banfield JF (2014) Elevated temperature alters proteomic responses of individual organisms within a biofilm community. ISME J. doi:10.1038/ismej.2014.113

Mueller DR, Vincent WF, Pollard WH, Fritsen CH (2001) Glacial cryoconite ecosystems: a bipolar comparison of algal communities and habitats. Nova Hedwigia Beiheft 123:173-198

Nadeau TL, Castenholz RW (2000) Characterization of psychrophilic oscillatorians (cyanobacteria) from Antarctic meltwater ponds. J Phycol 36:914-923

Namsaraev Z, Mano M-J, Fernandez R, Wilmotte A (2010) Biogeography of terrestrial cyanobacteria from Antarctic ice-free areas. Ann Glaciol 51:171-177

Neilan BA, Pearson LA, Muenchhoff J, Moffitt MC, Dittmann E (2013) Environmental conditions that influence toxin biosynthesis in cyanobacteria. Environ Microbiol 15:1239-1253

$\mathrm{Ng} \mathrm{C}$ et al (2010) Metaproteogenomic analysis of a dominant green sulfur bacterium from Ace Lake. Antarctica Isme J 4:1002-1019. doi:10.1038/ismej.2010.28

Nichols CA, Guezennec J, Bowman JP (2005) Bacterial exopolysaccharides from extreme marine environments with special consideration of the southern ocean, sea ice, and deep-sea hydrothermal vents: a review. Mar Biotechnol (NY) 7:253-271. doi:10.1007/s10126-004-5118-2

Niederberger TD, Sohm JA, Tirindelli J, Gunderson T, Capone DG, Carpenter EJ, Cary SC (2012) Diverse and highly active diazotrophic assemblages inhabit ephemerally wetted soils of the Antarctic Dry Valleys. FEMS Microbiol Ecol 82:376-390. doi:10.1111/j.1574-6941.2012.01390.x

Nienow J, Friedmann E, Ocampo-Friedmann R (2003) Endolithic microorganisms in arid regions. In: Bitton $\mathrm{G}$ (ed) Encyclopedia of environmental microbiology. Wiley, New York

Novis PM et al (2007) Annual carbon fixation in terrestrial populations of Nostoc commune (Cyanobacteria) from an Antarctic dry valley is driven by temperature regime. Global Change Biol 13:1224-1237

Oppenheim DR, Paterson DM (1990) The fine structure of an algal mat from a freshwater maritime Antarctic lake. Can J Bot 68:174-183

Oren A (2011) Cyanobacterial systematics and nomenclature as featured in the international bulletin of bacteriological nomenclature and taxonomy/international journal of systematic bacteriology/international journal of systematic and evolutionary microbiology. Int J Syst Evol Microbiol 61:10-15

Oren A (2014) Cyanobacteria: biology, ecology and evolution cyanobacteria: an economic perspective. Bioinformatics 20:1453-1454

Otero X, Fernandez S, de Pablo Hernandez M, Nizoli E, Quesada A (2013) Plant communities as a key factor in biogeochemical processes involving micronutrients ( $\mathrm{Fe}, \mathrm{Mn} \mathrm{Co}$, and $\mathrm{Cu}$ ) in Antarctic soils (Byers Peninsula, maritime Antarctica). Geoderma 195:145-154

Paerl H, Pinckney J (1996) A mini-review of microbial consortia: their roles in aquatic production and biogeochemical cycling. Microb Ecol 31:225-247

Pankow H, Haendel D, Richter W (1991) Die Algenflora der Schirmacheroase (Ostantarktika) Beihefte zur. Nova Hedwigia 103:1-195 
Papke RT, Ramsing NB, Bateson MM, Ward DM (2003) Geographical isolation in hot spring cyanobacteria. Environ Microbiol 5:650-659

Pearce DA et al (2012) Metagenomic analysis of a southern maritime Antarctic soil. Front Microbiol. doi:10.3389/fmicb.2012.00403

Petroff AP, Sim MS, Maslov A, Krupenin M, Rothman DH, Bosak T (2010) Biophysical basis for the geometry of conical stromatolites. Proc Natl Acad Sci USA 107:9956-9961

Philippot L et al (2013) Loss in microbial diversity affects nitrogen cycling in soil. ISME J 7:1609-1619. doi:10.1038/ismej.2013.34

Pinnaka AK, Singh A, Ara S, Begum Z, Reddy GS, Shivaji S (2013) Draft genome sequence of Leifsonia rubra strain CMS 76RT, isolated from a cyanobacterial mat sample from a pond in Wright Valley, McMurdo, Antarctica. Genom Announc. doi:10.1128/genomeA.00633-13

Podgorny IA, Grenfell TC (1996) Absorption of solar energy in a cryoconite hole. Geophys Res Lett 23:2465-2468

Pointing SB, Belnap J (2012) Microbial colonization and controls in dryland systems. Nat Rev Microbiol 10:551-562. doi: $10.1038 /$ nrmicro2831

Pointing SB, Belnap J (2014) Disturbance to desert soil ecosystems contributes to dust-mediated impacts at regional scales. Biodivers Conserv 23:1659-1667

Pointing SB, Chan Y, Lacap DC, Lau MC, Jurgens JA, Farrell RL (2009) Highly specialized microbial diversity in hyper-arid polar desert. Proc Natl Acad Sci USA 106:19964-19969. doi:10.1073/pnas. 0908274106

Powell L, Bowman J, Skerratt J, Franzmann P, Burton H (2005) Ecology of a novel Synechococcus clade occurring in dense populations in saline Antarctic lakes. Mar Ecol Prog Ser 291:65-80

Quiblier C, Wood S, Echenique-Subiabre I, Heath M, Villeneuve A, Humbert J-F (2013) A review of current knowledge on toxic benthic freshwater cyanobacteria-ecology, toxin production and risk management. Water Res 47:5464-5479. doi:10.1016/j.watres.2013.06.042

Rae BD, Long BM, Badger MR, Price GD (2013) Functions, compositions, and evolution of the two types of carboxysomes: polyhedral microcompartments that facilitate $\mathrm{CO} 2$ fixation in cyanobacteria and some proteobacteria. Microbiol Mol Biol Rev 77:357-379

Ramond JB, Makhalanyane TP, Tuffin MI, Cowan DA (2015) Normalization of environmental metagenomic DNA enhances the discovery of under-represented microbial community members. Lett Appl Microbiol. doi:10.1111/lam.12380

Reddy GS, Ara S, Singh A, Kumar Pinnaka A, Shivaji S (2013) Draft genome sequence of Psychrobacter aquaticus Strain CMS 56T, isolated from a cyanobacterial Mat Sample collected from water bodies in the McMurdo Dry Valley Region of Antarctica. Genom Announc. doi:10.1128/genomeA.00918-13

Rocak S, Linder P (2004) DEAD-box proteins: the driving forces behind RNA metabolism. Nat Rev Mol Cell Biol 5:232-241

Rochera C, Villaescusa JA, Velázquez D, Fernández-Valiente E, Quesada A, Camacho A (2013) Vertical structure of bi-layered microbial mats from Byers Peninsula, Maritime Antarctica. Antarct Sci 25:270-276

Ronca S, Frossard A, Guerrero LD, Makhalanyane TP, Aislabie JM, Cowan DA (2015) Draft genome sequence of Sphingomonas sp. strain Ant20, isolated from oil-contaminated soil on Ross Island, Antarctica. Genom Announc 3:e01309-e01314

Sabbe K, Hodgson DA, Verleyen E, Taton A, Wilmotte A, Vanhoutte K, Vyverman W (2004) Salinity, depth and the structure and composition of microbial mats in continental Antarctic lakes. Freshwater Biol 49:296-319

Santos HF et al (2014) Climate change affects key nitrogen-fixing bacterial populations on coral reefs. ISME J. doi:10.1038/ismej.2014.70

Schlesinger WH, Pippen JS, Wallenstein MD, Hofmockel KS, Klepeis DM, Mahall BE (2003) Community composition and photosynthesis by photoautotrophs under quartz pebbles, Southern Mojave Desert. Ecology 84:3222-3231. doi:10.1890/02-0549

Seckbach J, Oren A (2010) Microbial mats: modern and ancient microorganisms in stratified systems, vol 14. Springer, Berlin

Singh BK, Bardgett RD, Smith P, Reay DS (2010) Microorganisms and climate change: terrestrial feedbacks and mitigation options. Nat Rev Microbiol 8:779-790

Singh BK et al (2014) Loss of microbial diversity in soils is coincident with reductions in some specialized functions. Environ Microbiol. doi:10.1111/1462-2920.12353

Smith MC, Bowman JP, Scott FJ, Line MA (2000) Sublithic bacteria associated with Antarctic quartz stones. Antarct Sci 12:177-184

Stanish LF et al (2013) Bacteria and diatom co-occurrence patterns in microbial mats from polar desert streams. Environ Microbiol 15:1115-1131 
Steig EJ, Orsi AJ (2013) Climate science: the heat is on in Antarctica. Nat Geosci 6:87-88

Steven B, Pollard WH, Greer CW, Whyte LG (2008) Microbial diversity and activity through a permafrost/ground ice core profile from the Canadian high Arctic. Environ Microbiol 10:3388-3403

Steven B, Gallegos-Graves LV, Belnap J, Kuske CR (2013) Dryland soil microbial communities display spatial biogeographic patterns associated with soil depth and soil parent material. FEMS Microbiol Ecol 86:101-113. doi:10.1111/1574-6941.12143

Stibal M, Šabacká M, Kaštovská K (2006) Microbial communities on glacier surfaces in Svalbard: impact of physical and chemical properties on abundance and structure of cyanobacteria and algae. Microb Ecol 52:644-654

Stomeo F et al (2012) Abiotic factors influence microbial diversity in permanently cold soil horizons of a maritime-associated Antarctic Dry Valley. FEMS Microbiol Ecol 82:326-340. doi:10.1111/j.15746941.2012.01360.x

Strauss SL, Garcia-Pichel F, Day TA (2012) Soil microbial carbon and nitrogen transformations at a glacial foreland on Anvers Island, Antarctic Peninsula. Polar Biol 35:1459-1471

Strunecký O, Elster J, Komárek J (2012) Molecular clock evidence for survival of Antarctic cyanobacteria (Oscillatoriales, Phormidium autumnale) from Paleozoic times. FEMS Microbiol Ecol 82:482-490

Sutherland DL (2009) Microbial mat communities in response to recent changes in the physiochemical environment of the meltwater ponds on the McMurdo Ice Shelf, Antarctica. Polar Biol 32:1023-1032

Taton A, Grubisic S, Brambilla E, De Wit R, Wilmotte A (2003a) Cyanobacterial diversity in natural and artificial microbial mats of Lake Fryxell (McMurdo Dry Valleys, Antarctica): a morphological and molecular approach. Appl Environ Microbiol 69:5157-5169

Taton A, Grubisic S, Brambilla E, De Wit R, Wilmotte A (2003b) Cyanobacterial diversity in natural and artificial microbial mats of Lake Fryxell (McMurdo Dry Valleys, Antarctica): a morphological and molecular approach. Appl Environ Microbiol 69:5157-5169

Taton A, Grubisic S, Balthasart P, Hodgson DA, Laybourn-Parry J, Wilmotte A (2006) Biogeographical distribution and ecological ranges of benthic cyanobacteria in East Antarctic lakes. FEMS Microbiol Ecol 57:272-289

Thomas DN (2005) Photosynthetic microbes in freezing deserts. Trends Microbiol 13:87-88. doi:10.1016/j. tim.2004.11.002

Tolker-Nielsen T, Molin S (2000) Spatial organization of microbial biofilm communities. Microb Ecol 40:75-84

Turner J, King JC, Lachlan-Cope TA, Jones PD (2002) Climate change (communication arising): recent temperature trends in the Antarctic. Nature 418:291-292

Ugolini FC, Bockheim JG (2008) Antarctic soils and soil formation in a changing environment: a review. Geoderma 144:1-8. doi:10.1016/j.geoderma.2007.10.005

Valverde A, Makhalanyane TP, Seely M, Cowan DA (2015) Cyanobacteria drive community composition and functionality in rock-soil interface communities. Mol Ecol. doi:10.1111/mec.13068

Van Horn DJ et al (2013) Factors controlling soil microbial biomass and bacterial diversity and community composition in a cold desert ecosystem: role of geographic scale. PLoS ONE 8:e66103. doi:10.1371/ journal.pone.0066103

Varin T, Lovejoy C, Jungblut AD, Vincent WF, Corbeil J (2012a) Metagenomic analysis of stress genes in microbial mat communities from Antarctica and the High Arctic. Appl Environ Microbiol 78:549-559

Varin T, Lovejoy C, Jungblut AD, Vincent WF, Corbeil J (2012b) Metagenomic analysis of stress genes in microbial mat communities from Antarctica and the High Arctic. Appl Environ Microbiol. doi:10. 1128/AEM.06354-11

Velázquez D, Rochera C, Camacho A, Quesada A (2011) Temperature effects on carbon and nitrogen metabolism in some Maritime Antarctic freshwater phototrophic communities. Polar Biol $34: 1045-1055$

Verleyen E et al (2010) Structuring effects of climate-related environmental factors on Antarctic microbial mat communities. Aquat Microb Ecol 59:11-24

Vézina S, Vincent WF (1997) Arctic cyanobacteria and limnological properties of their environment: Bylot Island, Northwest Territories, Canada (73N, 80W). Polar Biol 17:523-534

Vincent WF (2000) Cyanobacterial dominance in the polar regions. The ecology of cyanobacteria. Springer, Berlin, pp 321-340

Vincent WF (2004) Microbial ecosystems of Antarctica. Cambridge University Press, Cambridge

Vincent WF (2007) Cold tolerance in cyanobacteria and life in the cryosphere. Algae and cyanobacteria in extreme environments. Springer, Berlin, pp 287-301

Vincent WF, Mueller DR, Bonilla S (2004) Ecosystems on ice: the microbial ecology of Markham Ice Shelf in the high Arctic. Cryobiology 48:103-112. doi:10.1016/j.cryobiol.2004.01.006 
Vyverman W et al (2010) Evidence for widespread endemism among Antarctic micro-organisms. Polar Sci 4:103-113. doi:10.1016/j.polar.2010.03.006

Wagner C, Adrian R (2009) Cyanobacteria dominance: quantifying the effects of climate change. Limnol Oceanogr 54:2460

Wharton RA Jr, Parker BC, Simmons GM Jr (1983) Distribution, species composition and morphology of algal mats in Antarctic dry valley lakes. Phycologia 22:355-365

Wharton RA Jr, McKay CP, Simmons GM Jr, Parker BC (1985) Cryoconite holes on glaciers. Bioscience 35(8):499-503

Wood SA, Mountfort D, Selwood AI, Holland PT, Puddick J, Cary SC (2008a) Widespread distribution and identification of eight novel microcystins in antarctic cyanobacterial mats. Appl Environ Microbiol 74:7243-7251. doi:10.1128/AEM.01243-08

Wood SA, Rueckert A, Cowan DA, Cary SC (2008b) Sources of edaphic cyanobacterial diversity in the Dry Valleys of Eastern Antarctica. ISME J 2:308-320. doi:10.1038/ismej.2007.104

Wynn-Williams D (1996a) Antarctic microbial diversity: the basis of polar ecosystem processes. Biodivers Conserv 5:1271-1293

Wynn-Williams D (1996b) Response of pioneer soil microalgal colonists to environmental change in Antarctica. Microb Ecol 31:177-188

Yergeau E, Newsham KK, Pearce DA, Kowalchuk GA (2007) Patterns of bacterial diversity across a range of Antarctic terrestrial habitats. Environ Microbiol 9:2670-2682. doi:10.1111/j.1462-2920.2007. 01379.x

Yergeau E et al (2008) Environmental microarray analyses of Antarctic soil microbial communities. Isme J 3:340-351. doi:10.1038/ismej.2008.111

Yergeau E, Hogues H, Whyte LG, Greer CW (2010) The functional potential of high Arctic permafrost revealed by metagenomic sequencing, qPCR and microarray analyses. ISME J 4:1206-1214

Yergeau E, Bokhorst S, Kang S, Zhou J, Greer CW, Aerts R, Kowalchuk GA (2012) Shifts in soil microorganisms in response to warming are consistent across a range of Antarctic environments. ISME J. doi:10.1038/ismej.2011.124

Yoshitake S, Uchida M, Koizumi H, Kanda H, Nakatsubo T (2010) Production of biological soil crusts in the early stage of primary succession on a High Arctic glacier foreland. New Phytol 186:451-460

Yung CC et al (2014) Characterization of chasmoendolithic community in Miers Valley, McMurdo Dry Valleys, Antarctica. Microb Ecol 68:351-359

Zablocki O, van Zyl L, Adriaenssens EM, Rubagotti E, Tuffin M, Cary C, Cowan D (2014) High diversity of tailed phages, eukaryotic viruses and virophage-like elements in the metaviromes of Antarctic soils. Appl Environ Microbiol 01525-01514

Zehr JP (2011) Nitrogen fixation by marine cyanobacteria. Trends Microbiol 19:162-173

Ziolkowski L, Mykytczuk N, Omelon C, Johnson H, Whyte L, Slater G (2013) Arctic gypsum endoliths: a biogeochemical characterization of a viable and active microbial community. Biogeosci Discuss 10:2269-2304 